\title{
International Migration Diversification: A New Perspective to Migration Management
}

\author{
Cynthia A. Bulley ${ }^{1} \&$ Peter Quartey ${ }^{2}$ \\ ${ }^{1}$ Central Business School, Central University College, Ghana \\ ${ }^{2}$ Economics Department, University of Ghana, Ghana \\ Correspondence: Cynthia A. Bulley, Central Business School, Central University College, Accra, Ghana. Tel: \\ 233-24-416-0060. E-mail: ayorkorb@hotmail.com
}

Received: March 4, 2014

Accepted: March 24, 2014

Online Published: April 24, 2014

doi: 10.5539/ibr.v7n5p21

URL: http://dx.doi.org/10.5539/ibr.v7n5p21

\begin{abstract}
Diversifying migration for development is an option that much has been discussed and yet little has been done in sending countries. The potential of international migration being harnessed for economic and social development have gained significant importance. Some initiatives have been discussed and launched to manage international migration. Some of these efforts are aimed at addressing the issue of containing the outflow and encouraging return of migrants to help with nation building. But these programmes are not adequate, and therefore more needs to be done. This study aims to review the international migration literature to examine the trend of migration and advocate for its diversification for development in sending countries. Some countries have courted the idea of diversifying migration but none have taken on the challenge. This study provides a precursor for policy makers to better understand international migration trends, options and strategies that can lead to diversification. The way forward for diversifying is a call for empirical studies to comparatively weight the options and develop short, medium and long term strategies. The question is whether policy makers in sub-Saharan Africa will take on the challenge to manage and transform international migration especially of the highly skilled. The paper calls for a different perspective in managing migration and contributes to the literature on international migration diversification for sending countries.
\end{abstract}

Keywords: diversification, international migration, development, highly skilled migrant, OECD

\section{Introduction}

\subsection{Introduction}

Globalisation and its attendant business opportunities bring interactions among countries in various ways. International migration a component of the globalisation process is increasing unabated. The introduction of a systematic selective international migration in a number of the Organisation for Economic Co-operation and Development (OECD) countries (Canada \& Australia) have opened an avenue for attracting highly skilled migrant. Though international migration have been connoted to mean deprivation for sending/source countries of human resources especially the flight of the highly skilled which erroneously have been equated to poverty and poor economic development, various research thwarted that claim (Kapur \& McHale, 2003; Clemens, 2007, de Haas, 2007). The long-term benefits accrued in the form of "counter flows" of remittances, knowledge/information, investments and innovation is encouraging research to determine the volume and account for it in sending countries.

The brain gain factor and remittances have made international migration of skilled professionals more complex. Irrespective of the economic crisis facing the developed countries, sub-Saharan Africa is still experiencing shortages of personnel in the health and education sectors especially. Even though the dimension is not as severe as in the period before the 'Great recession', the numbers are still a cause for concern. This is encouraging the clarion call for diversification of migration. Diversification calls for 'harvesting' the brain drain for economic development. This means policy makers would have to go beyond management to strategize and put in place tentative programmes and networks to take advantage of the phenomenon. Turner (2003), Kuznetsov (2006), Westcot (2006), Robinson (2007) and international organisations like the World Bank and UNESCO have researched extensively on the "actual developmental value" of international migration especially of the highly 
skilled. The various reviews and empirical studies fall short of calling for diversification as a strategy to manage international migration in specific sectors. However, the current rates of international migration of the highly skilled calls for drastic measures to control the movements whilst ripping the purported benefits. Diversification is not a new concept in relation to international migration, various sending countries in Asia and the Caribbean have used such measures to manage migration (Asis \& Agunias, 2012; Salmon et al., 2008). These countries have used planned migration programmes as a tool in the quest to manage the phenomenon. Sub-Saharan African countries can now look to these measures to devise strategies for effectively managing the phenomenon. But this calls for research and extensive analysis of the current situation. Also planned migration programmes could be examined based on quantitative analysis of its feasibility (Bulley, 2013).

Unfortunately, not much has been done in ascertaining the proper diversification and management of international migration and this forms the focus of the paper. The objective of this study is to review international migration, its management and ways of diversifying it for economic development. Specifically the size, trend and composition of migrants in OECD countries/destinations are examined to establish the current focus on international migration. Diversification issues and legislation direction are discussed. The case of a planned programme is highlighted. The paper is organized as follows: section one continues with a discussion on the key issues on migration management. It is then followed by an overview of international migration and then an analysis of the dimensions of migration. Section two outlines the methodology of the study followed by a section on the findings. The final section provides the concluding remarks.

\subsection{The Issue with Migration Management}

Despite the preoccupation of organisations and world economies with international migration, not much information exists on its management or diversification for economic growth in sub-Saharan Africa. Several studies have strongly linked international migration with development. The positive developmental impact of international migration is seen in research on migrant households, their remittances and investment patterns. This is leading to other multiplier effects in various sectors of sending countries' economies (Stark, 1991; Ratha, 2003; Kapur, 2003; Özden \& Schiff, 2005; World Bank, 2006). However, empirical studies on international migration diversification for economic development for sending/source countries in Africa are lacking. A Google scholar search revealed just 71,700 results for 'international migration diversification in Africa', 134,000 for 'international migration diversification' with only 148,000 on 'migration diversification'. Out of these numbers just 13 articles had issues relating to international migration diversification in Africa and migration. Oyelere's (2007) study on Kenyan international migration focused on the impact of their flight without including ways to overcome the situation. In Ghana, research on diversification of international migration or annexation for economic development is relatively neglected (Bulley, 2013). Notwithstanding this challenge, remittances for example are known to have improved for the better the economic conditions of migrant households and countries as a whole (Quartey, 2006). Robinson (2007) has called for the assessment of the "costs and benefits" analysis of health professional migration in the south, east and central Africa to warrant policies for future strategizing. The management of migration has been tackled from diverse perspective that is not yielding positive results and it is time to collate factual data to help with strategic plans. Therefore the call to diversify migration for development is in the right direction. Some migrant sending/source countries in Asia have put in place programmes to tap migration for economic development. The question is, can Africa move toward diversification? There is the need for this research to highlight the issues and bring out success cases to pave way for African countries to take up the mantle for empirical studies that would lead to diversifying international migration.

\subsection{International Migration Overview}

International migration has generated diverse theoretical and methodological perspective in its analysis. In examining the impact of migration, Johnson (1979), Grubel and Scott (1977) used the internationalisation models. This perspective examines human capital movements and its impact on countries. This perspective has been questioned by various researchers (Brimley, 1967; Ogilvie et al., 2007). Internationalisation models went through various modifications by various researchers like Bhagwati and Hamada (1974) and Bhagwati and Rodriquez (1975). The nationalist models emerged that considered the sending country population as its focus to determine migration impact on income and poverty in general. Desai, Kapur and McHane (2002) have resurrected the tenets of this model. Further, Stark (2004) and Beine et al. (2003) examined the positive impact of migration and their studies influenced the landmark empirical study by Clemens (2006) that concluded that international migration leads to human capital development. Diversifying international migration considers the net impact and goes further to examine beneficial brain drain models, strategies and networks (Turner, 2003). The basic preposition of these models is to determine the impact of international migration on economies and plan to manage it to a large extent. Migration phenomenon cannot be curtailed and it persists unabated. 
The issue of brain gain and remittances is another dimension that further makes migration management complex. In essence therefore, network theory and beneficial brain drain can be used to link up and integrate international migrant groups into formidable associations by sending countries.

The 2013 International Migration Outlook reports of increasing migration after the lower levels in times of the economic crisis period (OECD, 2013). OECD countries saw a $\%$ increase in total permanent immigration in 2011 relative to 2010. Trend analysis for selected OECD countries for 2011-2012 points to modest increases with higher rates for countries that rely on migrants to augment particular sectors (OECD, 2013). The direct recruitment by some OECD countries from 2005 (United Kingdom's direct recruitment of healthcare professionals through agencies in 2003, the Commonwealth code for the same purpose adopted in 2003 for example) and other direct access to health and education professionals has promoted the migration phenomenon in many developing countries irrespective of the prevailing 'Great Economic Crisis' in some developed countries in Europe and America. In Ghana for example an estimate of $46 \%$ of the population as compared to other West Africans migrate (IOM, 2009; Docquier \& Marfouk, 2006). Finding beneficial programmes for sending countries is an option that should be investigated.

\subsection{Dimension of Migration}

According to the most recent OECD data on international migration, there are about 222 million migrants in the world in 2013 as compared to 214 million in 2010. The 2010 figures rose by $2 \%$ in 2011 (about 4 million) and the same increase of $2 \%$ has been suggested for 2012 (OECD, 2013; PICUM, 2013). The total 'immigration' for the period 2001 to 2012 makes up $40 \%$ of the total population growth in the OECD countries. The analysis of international migrants in Europe indicates that 'fewer than one out of two' workers are employed from outside the OECD though 'immigration' inflow is growing.

The average annual net migration rates below, Figure 1 project 2005 to 2007 against 2008 to 2010 . From the figures, there are different levels of migration in each country and this is evident in the average annual net rates. The differences depend on how severe the Great Recession was in some countries. On the whole the OECD average annual net migration rate between 2008 and 2010 is positive (OECD, 2013).

\section{Per thousand population}

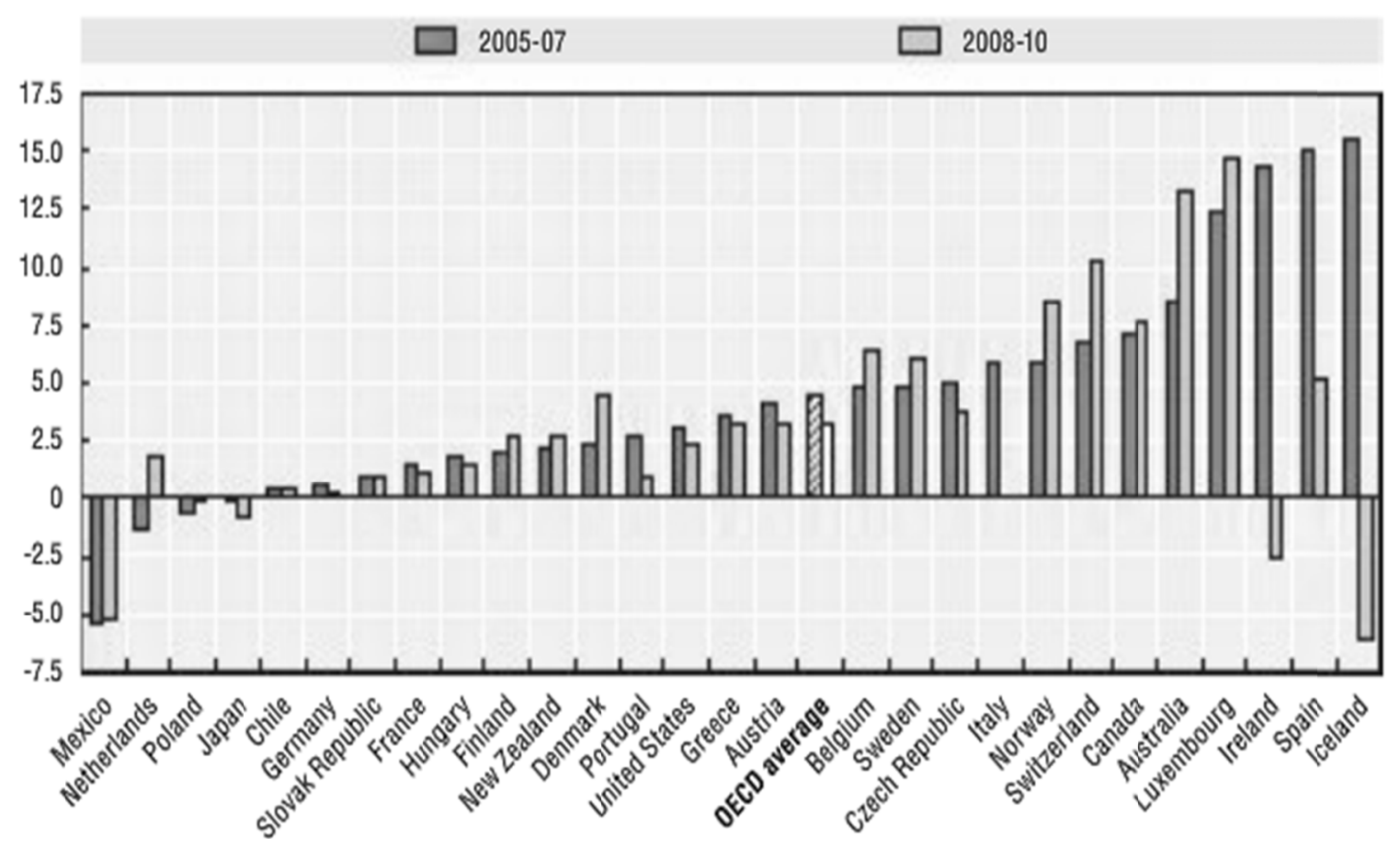

Figure 1. Average annual net migration rates, 2005-2007 and 2008-2010

Note. Averages for 2008-2010 are based on 2009-2010 for Australia and Ireland, on 2008 and 2010 for Japan and on 2008 for Greece. Source: OECD, Population and Vital Statistics Database' (OECD, 2013). 
Luxembourg, Australia, Switzerland, Norway, Sweden, Belgium, Canada, Denmark, and Netherlands have positive increases in migration movements over the period 2008 to 2010 with other OECD countries either experiencing a modest increase or decreasing. The recession in Europe and America have had tremendous effect on movements and migrants but its effects has not 'fundamentally changed the dynamics of international migration' (OECD, 2013). This is especially true for countries that require services of migrants to augment labour in particular sectors and industries. Countries like Luxembourg, Switzerland, Norway Austria and Australia were not adversely hit by the recession therefore the period between 2008 and 2012 saw no change in unemployment levels. In fact professional migration seems to have an advantage over the unskilled (OECD, 2013). The trends in international migration for 2011 and 2012 provide the overall picture of the migration situation in some major receiving countries.

\section{Methodology}

This study reviews international migration, its management and calls for diversification in sending/source countries to benefit from the phenomenon. A review of international migration literature was employed using secondary information sources. The search covered specific areas-international migration diversification in Africa, international migration, diversification and migration management. Academic journal articles were targeted and triangulated to address the objectives of the study. Triangulation provided a unique insight into the various migration management programmes and set the tone for the examination of diversification as an option for sending countries. The aim of the exploratory method applied is to develop a well grounded review and formulate more precise questions that future studies can address.

\section{Findings}

\subsection{The Current Trend of Migration (2011-2013)}

The current trend of international migration looks promising from the figures in Table 1. The preliminary statistics indicates that international migration flow experienced modest increases for the period 2011 to 2012. This confirms World Migration Report (2011) and OECD (2013) argument that it is gradually picking up at a slow rate comparatively to the pre-economic crisis - recession period in Europe and America. The preliminary trends below cover varying periods within 2011 and 2012 but the least period is 6 months for Poland. The totals reflect the annualized information for the period. From the table, though Australia experienced $15 \%$ positive change during the 12 months period covered, in absolute terms, United States' $-3 \%$ is far greater. United States and United Kingdom are large international migration countries but saw reductions of $-3 \%$ and $-16 \%$ respectively. The reductions in the volume of international migration in the United Kingdom is not due to the economic crisis but rather to the recent clamp down on illegal immigrant and "refused asylum seekers" in 2011 and 2012 (Hurrell, 2010).

Table 1. Preliminary trends in international migration in OECD countries in 2012 (adapted from OECD, 2013).

\begin{tabular}{lccccc}
\hline & 2011 & 2012 & \% change 2012/2011 & Period covered 2012/2011 & Number of Months \\
\hline Australia & 210700 & 242400 & 15 & July-June & 12 \\
Austria & 85100 & 99600 & 17 & January-September & 9 \\
Canada & 189100 & 194500 & 3 & January-September & 9 \\
Czech Republic & 18600 & 22000 & 18 & January-December & 12 \\
Denmark & 48200 & 52900 & 10 & January-October & 10 \\
Finland & 19700 & 18100 & -8 & January-October & 10 \\
France (excluding EU) & 128100 & 134500 & 5 & January-December & 12 \\
Germany & 842000 & 966000 & 15 & January-December & 12 \\
Iceland & 2800 & 2800 & 3 & January-December & 12 \\
Ireland & 33700 & 32100 & -5 & May-April & 12 \\
Mexico & 21500 & 20700 & -3 & January-December & 12 \\
Netherlands & 163000 & 155700 & -4 & January-December & 12 \\
New Zealand & 44500 & 42600 & -4 & July-June & 12 \\
\hline
\end{tabular}




\begin{tabular}{|c|c|c|c|c|c|}
\hline Norway(excluding EU) & 24300 & 26300 & 8 & January-October & 12 \\
\hline Poland & 6900 & 6600 & -4 & January-June & 12 \\
\hline Spain & 419200 & 354500 & -15 & October-September & 12 \\
\hline Sweden & 67000 & 74100 & 11 & January-November & 12 \\
\hline Switzerland & 138600 & 146100 & 5 & September-August & 12 \\
\hline United Kingdom & 500000 & 421000 & -16 & October-September & 12 \\
\hline United States & 1082000 & 1031600 & -3 & October-September & 12 \\
\hline Total $^{1}$ & 4150900 & 4178500 & 1 & & \\
\hline
\end{tabular}

Note. The total ${ }^{1}$ is the sum of annualized national data. Source OECD, International Migration Database and National data sources" (OECD, 2013).

Currently international migration flows are rising in most receiving countries despite the economic slowdown. Some OECD countries in 2011 and 2012 amended their laws to encourage and "attract international graduate students into their labour market" (OECD, 2013). The quest for health and education professionals is still going on and very high, a trend that will continue to balance global shortages worldwide. Diversifying migration to examine strategic options is the way forward. Therefore diversifying migration into income generating channels for sending countries like the Philippines, India and Nepal can go on unabated.

\subsection{Diversification of Migration}

The first and prudent way to diversify and manage migration of skilled professionals is to determine the volume to help with policy decisions. From this point its conversion into an exporting activity or human capital temporary transfer can be planned. In diversifying migration the issue of international trade and legislation or policy strategies is the first point of call. Can migration which is a service be diversified? What are the necessary steps to take to manage the phenomenon? The General agreement on Trade in Services (GATS) has adequately classified services and migration can be placed under the framework as a service exporting activity. The adaptation of migration for other activities have been debated by different researchers and governments copiously (OECD, 2013; Poot \& Strutt, 2009). Iredale (2000) and Freeman (2006) have examined the interaction between migration and international trade. They have all argued for policies and strategies that would support migration of highly skilled personnel. It is in this light that Bhagwati et al. (1974) called for taxation of migrants to reap returns for economic development in sending countries.

The question of migration fostering export activity or other management procedure calls for international negotiations and bilateral agreements. These concessions need to be initiated by sending countries that have vested interest in bolstering negotiations on all fronts for diversifying migration. The development of policies and strategies in the OECD favours highly skilled migration. Consequently, the next step is to set up government agencies and departments to see to migration diversification, and this can be a step toward any plans and agreements. Some source/sending countries already have instituted arrangements like the Migration Forum in Asia, the Philippine government institutions for migration and other ministerial arrangements in countries like India, Benin, Morocco and Mali (Agunias \& Newland, 2012). Malaysia's liberalization policies to facilitate cross border movement of people especially in the health and education sectors. The aim of such institutions initially was to collect statistics, facilitate and monitor migrants. In fact facilitating and recruiting intermediaries are now becoming a part of migration especially of skilled migrants. In Asia, the facilitating agencies have become the nerve centre that sees to the welfare of the migrant.

Some receiving countries especially those in need of health and education professionals have clearly set up avenues to recruit personnel globally. In November 2011, the European Union developed a portal (http://ec.europa.eu/immigration/) to provide information to assist migrants and "foreign nationals". Other specific countries like Sweden have portals (www.sweden.se/work) that provide information on jobs, skills needed, 'online language training', qualifications equivalent checking procedure online and issues on work permits (OECD \& DGM, 2012). There is the need to institutionalize and intensify legislation and strategic policies to diversify and harness the migration phenomenon

\subsection{Policies and Legislation on Migration}

The European Union developed a policy that ensures cooperation between itself and 'third countries'. This policy is basically focused on monitoring and managing the inflow and outflow of migrants with the aim of 
reducing 'pressure' associated with the phenomenon. The policy—Global Approach to Migration Policy—GAM, (2005) aims at:

"Facilitation of labour migration, prevention and curbing of irregular migration and fostering the links between migration and the development of migrants' countries of origin"

This document has been the basis of a number of other policies and legislation. In terms of its applicability, questions can be raised on policies pertaining to different regions or countries in the Union. In 2011, the GAM was renamed and a new aspect of security and the welfare of migrants were added. The new policy_-'Global Approach to Migration and Mobility' is more comprehensive and includes migrant source countries and how they can mobilize for future developments.

The UNCTAD, OECD and ILO have various policies and legislation on international migration especially. OECD countries between 2010 and 2012 are noted to have revised legislation and policies on international migration (OECD, 2013).

The ILO 'Plan for Action' in 2004 aims at mobilizing for the development of policies and programmes that promotes the positive aspect of migration whilst reducing the negatives. This framework has been used to develop various 'rights-based Multilateral' policies on labour migration.

The Association of South East Asia Nations (ASEAN) countries and other regional groups have put in place committees and global forums to address policies and legislation issues especially for the health labour industry. On the country to country level, specified legislations and policies exist but are these frameworks being mobilized to the advantage of each nation? The Baltic States (New Zealand, Romania and Bulgaria) 'free-circulation' programme was noted to have had 'high rate of emigration' in 2012. Australia and Canada were noted to have put in place policies to bring in skilled migrants. The United Kingdom introduced the 'comprehensive selection' programme in 2012. All these policies were put in place to overcome the dire situation of the recession. What programmes and policies are sending countries applying? Are these policies being revised to match current trends?

In sub-Saharan Africa, countries are fine-tuning policies and legislation especially with the economic crisis still looming. These countries are looking to new innovative policies and agreements that have return of migrant aspects to help to mobilize for development. In Ghana, legislation and policy situation is quite different. Ghana does not have defined policies on migration though several uncoordinated initiatives to tackle particular migration issues have been used at different instances. The Migration Unit under the Ministry of Interior is expected to coordinate and come up with a comprehensive policy for the country. There is the need for complete comprehensive policies if Ghana should consider the idea of a planned programme in the health and education sectors.

\subsection{The Case of Planned Programmes}

Planned migration programmes are not new in some countries with high rate of migration. The early 1970s and 1980s saw dramatic moves in contractual labour migration for highly skilled persons in areas like the Philippines, Indonesia, Nepal and Thailand. According to Go (2005) during the period 1975 to 1979, the Philippines saw 67.4\% of the total number of their workforce migrating. In the case of Thailand, between 1990 to the middle of 2000 about 200,000 workers migrated to the Gulf States and other Middle Eastern countries (Kanchai \& Kaung, 2005). Various high migrating country governments have re-examined the phenomenon and enacted liberalized policies, putting in place legislation to harness and streamline the highly educated personnel migration. Health and education professional migration have had complex effects on these countries. The Philippines, Indonesia and Nepal are major source countries for migration that have planned and monitored temporary migration programmes that sees to training, contracting, preparing migrants before departure and monitoring their welfare overseas. Asis and Agunias (2012) in a brief issue for IOM confirms governments role in harnessing and managing international migration in these countries. In their examination of the 'Overseas Employment Programmes' pre-departure' training, Asis et al. (2012) have estimated a total of 2,018 million workers leaving the Philippines, Indonesia and Nepal as indicated in Table 2 below for the period 2006 to 2010. 
Table 2. Annual deployment of migrant workers indicating the percentage of female migrant, 2006-2010 (adapted from Asis et al., 2012)

\begin{tabular}{|c|c|c|c|c|c|}
\hline Country & 2006 & 2007 & 2008 & 2009 & 2010 \\
\hline Indonesia & $680,000(79.7 \%)$ & $696,746(78.1 \%)$ & $748,825(74.3 \%)$ & $632,172(83.7 \%)$ & $575,804(78.4 \%)$ \\
\hline Philippines $^{1}$ & $788,070(60.0 \%)$ & $811,070(47.7 \%)$ & $974,399(48.3 \%)$ & $1,092,162(52.8 \%)$ & $1,123,676(54.5 \%)$ \\
\hline Nepal & $204,533(0.2 \%)$ & $249,051(1.9 \%)$ & $219,965(3.9 \%)$ & $294,094(3.4)$ & N/A \\
\hline
\end{tabular}

Note. Philippines ${ }^{1}$ collect data for both land and sea-based workers but for easy comparison with the two countries only land based (new and rehires) workers are considered in this case. The percentage of female migrant considers new hires for 'land-based Filipino workers. The total for both land and sea based workers can be found in Table 3 in the Philippine case review.

N/A = Not Available

Data Source: Indonesia $=$ Bachtiar, 2011; Philippines $=$ POEA, 2010; Nepal $=$ Social Science Baha, 2011. Information $=$ current through .

November, 2010.

These three countries have established and used migration as a means for economic development in varying forms. The aim of the programmes is to provide the professionals with education, training and equipping them for temporary migration.

\subsubsection{The Philippines Case}

In the case of the Philippines, the government has taken some measures to manage the overwhelming migration of both skilled and unskilled workers. The Philippines Overseas Employment Administration (POEA) programme initiated by the government in the early 1974 was to streamlined international migration. The Republic Act 8042 of 1995 was also passed in the Philippines to address migrant workers and those overseas issues. This legislation set forth to realign recruitment, deployment and manage welfare issues for Filipino migrant workers. It became a document that saw to the deployment, 'protection and promotion' of migrants. The Philippines 'medium-term plan' (2004-2010) initiated a one million deployment of workers for international migration yearly which was accomplished as per Table 3 (IOM \& MPI, 2012; Asis et al., 2013). The 2011 to 2016 plan did not clearly set yearly targets but deployment, education and monitoring of persons under the programme is a main focus of the temporary labour migration policy.

Table 3. Annual deployment of migrant workers in the Philippines: 2006 to 2010

\begin{tabular}{ccccccc}
\hline Country & 2006 & 2007 & 2008 & 2009 & 2010 & Total \\
\hline Philippines $^{1}$ & $1,062,567$ & $1,077,623$ & $1,236,013$ & $1,422,586$ & 1,470826 & $6,269,615$ \\
\hline
\end{tabular}

Note. Philippines ${ }^{1}$ both land- and sea-based workers are included. "On average sea-based sector deployment accounted for $23.6 \%$ for the 2006 to 2010 period.

The Act and plan made way for the health sector to come out with strategies to manage the outflow of personnel (Lorenzo et al., 2005; ILO, 2005; Iredale et al., 2002). Other agencies like Unlad Kabayan Migrant Services Foundation Incorporated and Development Action for Women Network also came up with the necessary training to augment the education of the migrant.

The Human Resources for Health master plan was instituted by the government of the Philippines to see to a more organized and planned temporary migration. The aim of the programme is to assist, train and temporary relocate (migrate) workers to specific countries over a period of time. The programme systematized training of particular sector personnel to augment the home front supply to alleviate shortages within. This reduced international migration levels and the number of migrants who permanently leave the country. Between 1975 to 1979 the programme saw 31 out of every 100 people who left Philippines as international migrant reducing to 6 out of every 100 between 1995 to 1999 (Iredale et al., 2002).

\subsubsection{Lessons from the Philippines}

The initial steps taken to manage the phenomenal migration in the Philippines were to promulgate legislations and policies to facilitate the annexation process. Governmental sectors like POEA and other agencies were set up to come up with plans to harness the phenomenon. The plans were initiated and have been in existence in the 
Philippines for about 39 years. These organizations were tasked to educate, monitor and prepare migrants for the planned 'export'.

The next step saw to the development of exchange programmes through bilateral agreements with receiving countries. This called for bilateral arrangements on contract or temporary employment for fixed terms, mutually accepting to pave the way for sending country certification and licensing agreements. These contractual arrangements made room for the country to build domestic capacity to relief local shortages whilst training for export.

Furthermore, the Philippines programme manages the migrant in and out of the country, seeing to their health and welfare needs. The programme facilitates and controls migration while encouraging return migration especially in the health and education sector. This has made the healthcare sector for example to become attractive for school leavers. The Philippines is a leading country for the export of labour. The estimate of 9.4 million personnel in temporary exporting programmes in 2010 by the Commission on Filipino Overseas is by far one of the most successful (Dimaya et al., 2012). The success of the programme has ensured the constant supply of health personnel. Currently the Philippines have ' 418 nurses per 100,000 population against the United Kingdom's 497 per 100,000'.

These are lessons that other countries in Sub-Saharan Africa like Ghana can use as case studies, should the country decide to take up the challenge to diversify and manage migration in the health and education sectors.

\section{Discussion}

\subsection{Diversification and Management}

The call to manage international migration in developing countries seems like a daunting task since its components are diverse and complex. Migration management involve short, medium and long term programmes and activities. Governments need to take up the initiative to empower institutions to coordinate and integrate migration activities. Such holistic integration should consider all parties involved - agencies, sector institutions in conjunction with international best practice from organisations. Secondly, there is the need to strategize and institute a holistic and integrated programme that considers policies to maximise the advantages and reduce the negative aspect of international migration. The clarion call for comparative data on the number of migrants overseas or near accurate estimates of the overall total migrant and differentiation in terms of skill levels is a necessary step to managing the flow. Another important step is to motivate specific skills and professions that have low resistance to migration. Incentives and provision of work infrastructure should be incorporated in government side of activities to manage international migration. As de Haas (2007) has pointed out, international migration management must include "strategies" for diversifying that would lead to positive effects on sending/source country economy.

Diversification seems challenging due to bi-lateral and multi-lateral agreements that need to be put in place to set the process rolling. This is due to the different institutions involved and policies pertaining in various countries. Nevertheless, it is a necessary option. Diversification will call for strategising to harness migration in certain sectors to revamp, develop and introduce a planned programme. Policies, multi- and bi-lateral arrangements should be in place for such endeavours. Beneficial brain drain can be introduced through such planned international migration programmes in particular sectors. Goswami, Mattoo and Sáez (2011) have concluded that the Philippines success in diversifying international migration through service exports is due to "liberalisation". Every major sector was liberalized to manage 'brain drain' and increase domestic capacity making diversification into exports a matter of course. Increasing domestic capacity of human capital it is argued will benefit sending countries domestically. This is in line with Malaysia's change in visa and immigration policies that aided the diversification of international migration into service export especially in the health and education sectors (Goswami et al., 2011).

Building of networks of professionals in the Diaspora to tap their knowledge can move a stage forward to introduce internet and web registration programmes. The database would be a source for interacting and communicating important information. These programmes should be monitored with constant research on return migrants, their reintegration and contributions to development. In addition, remittances can also be monitored closely, removing all impediments to attract more inflows. Evidence specific studies would be the next line of action to collect systematic and quantitative data that would address the feasibility of diversification of international migration in sending/source countries.

\section{Conclusion}

The discussion indicates that there is the need for more coherent international migration management 
programmes. This should be coordinated in sending/source countries and receiving countries to facilitate its management. Migration diversification is a new area that calls for extensive research and quantitative analysis. The current trend of migration indicates that international migration flow is still experiencing modest growth with some countries encouraging international graduate students and professionals into their labour market. Migration researchers predicted increases overtime but the economic crisis managed to reduce its flows modestly. The 2010 trend showed a mixed rate of flow, picking up in 2011 and 2012. Diversification therefore is an option that would monitor, manage and control migration for sending countries. This calls for policies and legislations on migration which has long been in place. The European Union's policy that ensures cooperation between itself and 'third countries', the Global approach to Migration and Mobility policy, UNCTAD, OECD and ILO policies are promoting such quest to turn migration into a service export activity. This implies that organisational strategies and networks are the first essential planning tools for diversification. The case of the planned migration programme in the Philippines is a classic case that could be benchmarked by other countries.

The government of the Philippines has used legislation and policy strategies that can be sited as one of the best means of managing migration. International recruitment network play a vital role in the Philippines programme. Also bilateral agreement that leads to all parties benefiting is a necessity and this is facilitating migration diversification.

In conclusion, the need to diversify international migration flows and management is timely but it calls for the strengthening of data generation and management systems that would facilitate a broader examination of diversification as a strategic tool to manage international migration.

\section{References}

Agunias, D., \& Newland, K. (2012). Building Diaspora Institutions: Carving a Niche in the Inner Workings of Government. Developing a Road Map for Engaging Diasporas in Development: A Handbook for Policymakers and Practitioners in Home and Host Countries. Geneva: International Organisation for Migration (IOM). Retrieved from http://www.gfmd.org/diasporahandbook

Anarfi, J., Quartey, P., \& Agyei, J. (2010). Key Determinants of Migration among Health Professionals in Ghana. Retrieved from http://www.Quartey_et_al_Health_Workers.pdf

Asis, M. B., \& Agunias, D. R. (2012). Strengthening Pre-departure Orientation Progrmmes in Indonesia, Nepal and the Philippines. Issues in Brief, 5. Bangkok \& Washington DC: IOM \& MPI.

Beine, M. (2003). Measuring international skilled migration: a new database. European Economic Review, 47(5), 891-911. http://dx.doi.org/10.1016/S0014-2921(02)00306-9

Bhagwati, J. N., \& Hamada, K. (1974). The Brain Drain, International Integration of Markets for Professional and Unemployment: A Theoretical Analysis. Journal of Development Economics, 1(1), 19-42. http://dx.doi.org/10.1016/0304-3878(74)90020-0

Bhagwati, J. N., \& Roderiguez, C. (1975). Welfare-Theoretical Analyses of the Brain Drain. Journal of Development Economics, 2, 195-221. http://dx.doi.org/10.1016/0304-3878(75)90002-4

Brimley, D. T. (1967). The International Circulation of Human Capital. Retrieved from http://www.springerlink.com/content/tn2252537q311j10/resource-secured/?target=future

Bulley, C. A. (2013). Harnessing Migration for Service Export from Sub Saharan Africa: A New Dawn for An Age Old Phenomenon. International Journal of Business \& Management, 8(22). http://dx.doi.org/10/5539/ijbm.v8n22p65

Clemens, M. A. (2007). Do Visas Kill? Health effects of African Health Professional Emigration. Working Paper No. 14. Center for Global Development, Washington, DC. Retrieved from www.cgdev.org/files/13123_Clemens_Do_visas_kill_3_.pdf

De Haas, H. (2007). The Impact of International Migration on Social and Economic Development in Morocco Sending Regions: A Review of the Empirical Literature. Working Paper Number 3. International Migration Institute, University of Oxford. Retrieved from http://www.WP3-Migration Impact Morocco.pdf

Desai, M., Kapur, D., \& McHane, J. (2002). The Fiscal Impact of High Skilled Emigration: Flows of Indians to the US. Retrieved from http://www.people.hbs.edu/mdesai/fiscalimpact.pdf

Dimaya, R. M., McEwen, M. K., Curry, L. A., \& Bradley, E. H. (2012). Managing Health Worker Migration: A Qualitative Study of the Philippines Response to Nurse Brain Drain. Human Resource for Health. http://dx.doi.org/10.1186/1478-4491-10-47 
Docquier, F., \& Marfouk, A. (2005). International Migration by Education Attainment (1990-2000). In Ozden, C. \& Schiff (Eds.), International Migration, Remittances and the Brain Drain, Chapter 5. Palgrave-Macmillan.

Freeman, R. B. (2006). People Flows in Globalization. Journal of Economic Perspective, 20(2), 145-170. http://dx.doi.org/10.1257/jep.20.2.145

Go, S. P. (2005). Migration Research and Policy Landscape: Case Studies of Australia, the Philippines and Thailand. Retrieved from http://unesco.org/images/0014/001411/141125eo.pdf

Goswami, A. G., Mattoo, A., \& Sáez, S. (2011). Exporting Services: A Developing Country Perspective. Retrieved from http://www.1686-exporting-services-a-developing-country-perspective-paper-pdf

Grubel, H., \& Scott, A. (1977). The Brain Drain: Determinants, Measurement and Welfare Effects. Waterloo, Ontario, Canada: Wilfred Laurier Press.

Hurrell, A. (2010). Performance Politics: Building Public Confidence in Immigration Policy. Seminar Report Policy Network, London. Retrieved from http://www.gfmd.org/documents/mauritius/gfmd12_mauritius12_rt_3-1-background_paper_en.pdf

Ibid. (2004). Rethinking the Brain Drain. World Development, 32(1), 15-22. http://dx.doi.org/10.1016/j.worlddev.2003.06.013

IOM. (2009). Retrieved from http://www.iom.int

IOM. (International Organisation of Migration) \& MPI. (Migration Policy Institute) (2012). Strengthening Pre-departure Orientation Programmes in Indonesia, Nepal and the Philippines. Issue in Brief, September, 5. Retrieved from http://www.predepartureorientationPLAN.pdf

Iredale, R. (2000). Migration Policies for the Highly Skilled in the Asia-Pacific Region. International Migration Review, 34(3), 882-906. http://dx.doi.org/10.2307/2675948

Iredale, R., Turpin, T., Hawksley, C., Go, S., Kanchai, S., \& Kuang, Y. M. (2002). Migration Research and Policy Landscape: Case Studies of Australia, the Philippines and Thailand. In Kerry L. (Ed.). Asia Pacific Migration Research Network of UNESCO. Working Papers Series, No. 9.

Johnson, N. (2009). Analysis and Assessment of the Brain Drain Phenomenon and its Effects on Caribbean Countries. Florida Atlantic Comparative Studies Journal, 11, 2008-2009. Retrieved from http:/home.fau.edu/peralta/web/FACS/braindrain.pdf

Kanchai, S., \& Kaung, M. (2005). Migration Research and Migration Policy Making: A case Study of Thailand. The Asian Research Center for Migration Institute of Asian Studies, Chulalongkorn University. Retrieved from http://unesco.org/images/001411/141125eo.pdf

Kapur, D. (2003). Remittances: The New Development Mantra. Paper prepared for the G-24 Technical Group Meeting. United Nations Conference on Trade and Development. Retrieved from http://unctad.org/en/Docs/gdsmdpbg2420045-en.pdf

Kapur, D., \& McHale, J. (2003). Migration New Payoff. Foreign Policy, 139(November/December), 48-57. http://dx.doi.org/10.2307/3183737

Kuznetsov, Y. (2006). Leveraging Diasporas of Talent: Toward a New Policy Agenda. In Y. Kuznetsov (Ed.). Diaspora Networks and the International Migration if Skills: How Countries can Draw on their Talent Abroad. Washington DC.: World Bank. http://dx.doi.org/10.1596/978-0-8213-6647-9

Lorenzo, F. M., Galvez-Tan, J., Icamina, K., \& Javier, L. (2005). Nurse Migration from a Source Country Perspective: Philippine Country Case Study. Health Research and Educational Trust. France. Retrieved from http://www.ncbi.nlm.nih.gov/pmc/articles.PMC1955369/pdf/hesr0042.pdf

OECD. (2013). International Migration Outlook 2013. OECD Publishing. Retrieved July, 8, 2013 from http://dx.doi.org/10.1787/migr_outlook-2013-en

Ogilvie, L., Mill, J. E., Astle, B., Fanning, A., \& Opare, M. (2007). The Exodus of Health Professionals from Sub-Saharan Africa: Balancing Human Rights and Societal Needs in the Twenty First Century. Nursing Inquiry, 14(2), 114-124. http://dx.doi.org/10.1111/j.1440-1800.2007.00358.x

Oyelere, R. U. (2007). Brain Drain, Waste or Gain? What we know about the Kenyan case. Journal of Global Initiatives, 2(2), 113-129. Retrieved from http:// www.oyelereglobal.pdf

Özden, C., \& Schiff, M. (2005). International Migration, Remittances, and the Brain Drain. Washington DC.: 
The International Bank for Reconstruction and Development/The World Bank. Palgrave Macmillan division of St. Martin's Press, LLC of Palgrave Macmillan Limited. Retrieved from https://openknowledge.worldbank.org/bitstream/.../339880rev.pdf

PICUM. (2013). Bulletin of the Platform for International Cooperation on Undocumented Migrants (PICUM). Retrieved from http://picum.org/en/news/bulletins/397641

Poot, J., \& Strutt, A. (2009). International Trade Agreements and International Migration. Working Paper in Economics. Retrieved from http://ideas.repec.org/a/bla/worlde/v33y2010i12p1923-1954.html

Quartey, P. (2006). The Impact of Migrant Remittances on Household Welfare in Ghana. African Economic Research Consortium, Nairobi. AERC Research Paper 158. Retrieved from http://www.aercafrica.org/documents/rp158.pdf

Ratha, D. (2003). Workers' Remittances: An Important and Stable Source of External Development Finance (pp. 157-175). In Global Development, 2003. Washington DC.: World Bank. Retrieved from $\mathrm{http} / / /$ siteresources.worldbank.org/INTRGDF/Resources/GDF2003-Chapter7.pdf

Robinson, R. (2007). The Costs and Benefit of Health Worker Migration from East and Southern Africa: A Literature Review. Regional Network for Equity in Health in East and Southern Africa (EQUINET) in co-operation with Health Systems Trust and the East, Central and Southern African Health Community. Supported by SIDA Sweden. EQUINET Discussion Paper 49. Retrieved from www.nsi-ins-ca/wp-content/uploads/2012/10/2007-the-costs-and-benefits-of-health-worker-migration-fromeast-and-sounthern-africa-ESA-A-literature-Review.pdf

Salmon, M. E., Yan, J., Hewitt, H., \& Guisinger, V. (2008). Managed Migration: The Caribbean approach to addressing nursing services capacity. Health Research and Educational Trust. Retrieved April, 18, 2011 from http://findarticles.com/p/articles/mi_m4149/12

Stahl, C. W., \& Appleyard, R. T. (2007). Migration \& Development in the Pacific Islands: Lessons from the New Zealand Experience. Australian Agency for International Development (AusAID). Retrieved from http://www.migration.pdf

Stark, O. (1991). The Migration of Labour. Cambridge \& Oxford: Blackwell Publishers. Retrieved from http://www.demografi.bps.go.id/.../bahan/.../Oded_Stark_Migrationoflabour.pdf

Turner, W. A. (2003). Diaspora Knowledge Networks. Paris: UNESCO. Retrieved from http://portal.unesco.org/shs/en/files/4783/10841746551diaspora_knowledge_networks_Draft_proposal.pdf

UNESCO. (2006). Global Education Digest. New York: United Nations Education, Scientific, and Cultural Organisation. Retrieved from http://unesco.org

Wescott, C. (2006). Harnessing Knowledge Exchange among Overseas Professionals. International Public Management Review, $7(1), \quad 30-69 . \quad$ Retrieved from http://www.unitarny.org/mm/file/ADB\%20knowledge\%20exchange.pdf

World Bank. (2006). Global Economic Prospects 2006: Economic Implications of Remittances \& Migration. Washington DC.: World Bank. Retrieved from http://wwww.worldbank.org

World Migration Report. (2011). Communicating Effectively about Migration. Retrieved from http://publications.iom.int/bookstore/free/WMR2011_English.pdf

World Migration Report. (2011). International Migration Report 2009: A Global Assessment. United Nations, Department of Economic and Social Affairs-Opulation Division. Retrieved from http://www.un.worldmigrationreport2009/pdf

\section{Copyrights}

Copyright for this article is retained by the author(s), with first publication rights granted to the journal.

This is an open-access article distributed under the terms and conditions of the Creative Commons Attribution license (http://creativecommons.org/licenses/by/3.0/). 